\title{
FAKTOR-FAKTOR YANG MEMPENGARUHI PENDUDUK LANJUT USIA MEMILIH UNTUK BEKERJA
}

\author{
Moch. Affandi \\ Fakultas Ekonomi Universitas Brawijaya
}

\begin{abstract}
This study analysis the determinant of the old generations workers (more than 60 years old) to work or to enter teh labour market. Using Sakerti data, it can be seen that they have low level of education, low level of family expenditure, are living in the rural area and working in the informal sector. Generally, the condition of family economy is the main determinant for old generation workers to work or join the labour market. Therefore, there is a need to prepare the work conditions and activities that fit for old generation workers due to the fact they are not productive anymore in term of employment.
\end{abstract}

Keywords: old generation workers, labour market and informal sector

\section{A. LATAR BELAKANG}

Pertumbuhan penduduk lanjut usia (lansia) diprediksikan akan meningkat cepat dimasa yang akan datang terutama di negara-negara berkembang. Indonesia sebagai salah satu negara berkembang juga akan mengalami peledakan jumlah penduduk lansia. Pada mulanya proporsi penduduk lansia di Indonesia relatif rendah yaitu sekitar 4,5 persen tahun 1971. Tetapi antara tahun 1990 (6,6 persen) hingga tahun 2020 (11 persen) kenaikan secara mencolok akan terjadi pada persentase penduduk lansia, kenaikannya hampir dua kali lipat (BPS 1998).

Hal yang menarik untuk dibahas dengan terjadinya peningkatan penduduk lansia ini adalah pandangan bahwa lansia bergantung kepada bagian penduduk yang lain, terutama pada pemenuhan kebutuhan hidupnya. Selain itu, keberadaan lansia juga dikaitkan dengan perhitungan rasio ketergantungan, yang merupakan perbandingan antara penduduk usia produktif dengan penduduk usia non produktif termasuk di dalamnya adalah lansia. Jika penduduk lansia tersebut semakin meningkat jumlahnya, maka beban penduduk usia produktif akan semakin besar.

Namun, pada kenyataannya masih banyak lansia yang bekerja untuk mencari nafkah, seperti terlihat dari data Survei Angkatan Kerja Nasional (SAKERNAS) tahun 1996, dari 2,6 juta lansia laki-laki yang berusia 60-64 tahun, 81 persen diantaranya berstatus bekerja (BPS 1997). Bahkan untuk lansia yang sudah berusia 65 tahun ke atas masih banyak yang bekerja, yaitu sebesar 57 persen dari 3,8 juta lansia usia tersebut. Data SAKERNAS juga memper lihatkan bahwa sekitar 45 persen lansia perempuan usia 60-64 tahun.Hal tersebut menunjukkan bahwa umumnya lansia di Indonesia masih dapat melakukan berbagai aktivitas dan masih banyak berperan dalam kehidupan keluarga dan masyarakat, seperti juga dikemukakan oleh Suhartinah (1998). Tidaklah mengherankan bila pada kenyataannya lansia di Indonesia masih banyak yang harus bekerja, dan yang mempunyai kemauan dan kemampuan untuk bekerja.

Banyaknya lansia yang masih bekerja di satu pihak dapat menunjukkan bahwa lansia memang masih aktif di pasar kerja dan berusaha untuk tidak tergantung pada penduduk lainnya, tapi di pihak lain dapat menjadi masalah jika mereka tidak diperhatikan sebagaimana mestinya. Meskipun lansia masih banyak yang bekerja, namun upah yang mereka terima umumnya kurang dari 300 ribu rupiah perbulan (BPS, 1998). Hanya 11,6 persen lansia yang berusia 60-64 tahun yang 


\section{Journal of Indonesian Applied Economics \\ Vol. 3 No. 2 Oktober 2009, 99-110}

menerima upah lebih dari 300 ribu rupiah perbulan. Dengan upah sebesar tersebut mungkin dirasa sudah cukup memenuhi kebutuhan sehari-hari, namun sulit untuk mencapai tingkat kehidupan lansia yang berkualitas. Oleh karena itu perlu bantuan dari semua pihak akan nasib lansia tersebut hingga mencapai lansia yang tetap berkualitas dan berguna.

Banyaknya lansia yang masih bekerja disebabkan oleh kebutuhan ekonomi yang relatif masih besar, serta secara fisik dan mental lansia tersebut masih mampu melakukan aktivitas sehari-hari. Kebutuhan ekonomi yang relatif besar pada lansia kemungkinan disebabkan tidak/belum adanya jaminan sosial ekonomi yang memadai bagi lansia. Di Indonesia jaminan hari tua, seperti uang pensiun masih sangat terbatas untuk mereka yang bekerja di sektor formal saja, tidak untuk sektor informal. Oleh karena itu, perlu dipikirkan berbagai upaya untuk menjangkau lansia yang tidak punya pensiun atau jaminan hari tua., mengingat jumlah mereka lebih banyak dibanding lansia dari sektor formal.

Melihat situasi tersebut maka dampak dari pertambahan penduduk lansia ini perlu segera diantisipasi dan mendapat perhatian serta penanganan, mengingat secara umum kondisi lansia berbeda dengan kondisi penduduk lainnya. Berbagai upaya pemecahan masalah sudah harus segera dipikirkan dan diper timbangkan agar penduduk lansia tidak menjadi kendala pembangunan, tetapi tetap dapat dipertahankan sebagai modal pembangunan. Meskipun dalam hal ini peran mereka mungkin berbeda dengan peran penduduk muda, mengingat kondisi fisik, mental dan sosial mereka yang sudah banyak mengalami kemunduran. Idealnya lansia yang bekerja mempunyai pekerjaan yang sesuai dengan kondisi fisik dan mental serta bagi lansia yang tidak bekerja diharapkan kesejahteraan mereka juga masih tetap mendapat perhatian. Jika kondisi seperti ini dapat terwujud dengan baik, maka berbagai pandangan bahwa lansia bergantung kepada bagian penduduk yang lain dalam pemenuhan kebutuhan dapat dikurangi.

\section{B. KAJIAN TEORITIS}

Sebelum membahas lebih lanjut program-program kesejahteraan lansia masa depan ada baiknya dikemukakan terlebih dahulu konsep-konsep yang berkaitan dengan lansia. Secara individu, seseorang disebut sebagai lansia jika telah berumur 60 tahun ke atas (di negara berkembang) atau 65 tahun ke atas (di negara maju). Di antara lansia yang berusia 60 tahun ke atas dikelompokkan lagi menjadi young old (60-69 tahun), old (70-79 tahun) dan old-old (80 tahun ke atas).

Dari aspek kesehatan, seseorang disebut sebagai lansia (elderly) jika berusia 60 tahun ke atas. Sedangkan penduduk yang berusia antara 49-69 tahun disebut sebagai pra-sensile. Lansia yang berusia 70 tahun ke atas disebut sebagai lansia beresiko.

Dari aspek ekonomi, lansia (60 tahun ke atas) dikelompokkan menjadi (1) lansia yang produktif yaitu lansia yang sehat baik dari aspek fisik, mental maupun sosial; dan (2) lansia yang tidak produktif yaitu lansia yang sehat secara fisik, tetapi tidak sehat dari aspek mental dan sosial; atau sehat secara mental tetapi tidak sehat dari aspek fisik dan sosial; atau lansia yang tidak sehat baik dari aspek fisik, mental maupun sosial.

Secara demografis, pengelompokan penuaan penduduk dapat dilihat dari beberapa ukuran yaitu dependency ratio, persentase penduduk lansia, dan dari sisi umur median penduduk. Dari dependency ratio suatu penduduk disebut sebagai penduduk tua jika dependency ratio penduduk tuanya sudah di atas 10 persen. Dari persentase penduduk lansia, struktur penduduk lansianya sudah mencapai 7 persen ke atas. Sedangkan dari umur median penduduk, sebuah penduduk disebut sebagai penduduk tua jika umur mediannya 30 tahun ke atas.

Proses penuaan merupakan hal yang kompleks, dan belum ditemukan secara pasti fenomena yang melandasi mekanisme penuaan tersebut. Karena itu, perlu kriteria untuk menyatakan penduduk usia tua (lansia). Untuk mendefinisikan istilah penduduk lansia (lanjut usia) bukanlah hal yang mudah. Beberapa aspek yang perlu dipertimbangkan untuk menentukan batasan penduduk lansia 


\section{Faktor-Faktor yang Mempengaruhi Penduduk Lanjut Usia}

Affandi

adalah aspek biologi, ekonomi, sosial, dan usia atau batasan usia, seperti disebutkan dalam buku "Data dan Informasi Penduduk Lansia di Indonesia" (BKKBN 1998).

Secara biologis, penduduk lansia adalah penduduk yang telah menjalani proses penuaan dalam arti menurunnya daya tahan fisik yang ditandai dengan semakin rentannya terhadap serangan berbagai penyakit yang dapat menyebabkan kematian. Hal ini disebabkan oleh meningkatnya usia, terjadi perubahan dalam struktur dan fungsi sel, jaringan serta, sistem organ. Proses penuaan berbeda dengan "pikun" (senila dmentia), yaitu perilaku aneh atau sifat pelupa dari seseorang di usia tua. Pikun merupakan akibat dari tidak berfungsinya beberapa organ otak, yang dikenal dengan penyakit Alzheimer.

Ditinjau dari aspek ekonomi, penduduk lansia secara umum dipandang lebih sebagai beban daripada potensi sumber daya bagi pembangunan. Warga tua dianggap sebagi warga yang tidak produktif dan hidupnya perlu ditopang oleh generasi yang lebih muda. Bagi penduduk lansia yang masih memasuki lapangan pekerjaan, dianggap produktifitasnya sudah menurun, sehingga pada umumnya pendapatannya lebih rendah dibandingkan yang diterima oleh penduduk usia muda. Namun demikian tidak semua yang termasuk dalam kelompok umur lansia ini memiliki kualitas dan produktifitas rendah. Pada sebagian penduduk, kualitas penduduk usia tua tidak kalah dibandingkan mereka yang berada dalam kelompok umur muda, sebab di usia senja mereka telah memiliki cukup pendidikan dan pengalaman yang belum tentu dimiliki oleh kaum muda.

Dari sudut pandang sosial, penduduk lansia merupakan suatu kelompok sosial tersendiri. Di negara Barat misalnya, penduduk lansia menduduki strata sosial di bawah kaum muda. Hal ini ditandai oleh keterlibatan mereka terhadap sumber daya ekonomi, pengaruh dalam pengambilan keputusan, serta luasnya hubungan sosial yang semakin menurun di usia tua. Namun di masyarakat tradisional di Asia pada umumnya, termasuk Indonesai, penduduk lansia menduduki kelas sosial yang tinggi, yang harus dihormati oleh masyarakat yang usianya lebih muda.

Dari beberapa aspek yang perlu dipertimbangkan dalam mendefinisikan penduduk lanjut usia, pendekatn usia adalah yang paling memungkinkan untuk digunakan . Batasan usia ini mudah untuk diimplementasikan karena informasi tentang usia hampir selalu tersedia pada berbagai sumber data kependudukan. Definisi penduduk lansia (lanjut usia) berbeda-beda tergantung pada yang mendefinisikan. Para demografer mendefinisikan penduduk lansia dengan batasan umur 65 tahun. Perserikatan Bangsa-bangsa (PBB) menggunakan batasan umur 60 tahun. Di Indonesia biasa digunakan batasan umur 60 tahun untuk mendefinisikan warga tua (kantor Menteri Negara Kependudukan/BKKBN, 1998). Sesuai dengan batasan umur penduduk lansia yang digunakan di Indonesia, tulisan ini menggunakan batasan umur 60 tahun untuk mendefinisikan penduduk lansia. Sedangkan batasan umur 65 tahun ke atas digunakan untuk memudahkan dalam membandingkan isu penduduk lansia di Indonesia dari sudut pandang internasional (Ananta et al 1998).

Noveria (2000), mengemukakan bahwa meskipun secara prosentase, penduduk usia lanjut di Indonesia tidak sebesar yang di miliki oleh negara-negara lain seperti Hongkong (14,3 persen), Singapora (9,6 persen) dan Korea Selatan ( 8,8 persen) pada tahun 1995, namun secara absolut jumlahnya lebih besar di Indonesia dibandingkan dengan negara-negara terebut.

Tingginya jumlah lansia tersebut tidak dibarengi dengan tingkat pendidikan dan pendapatan yang tinggi dan kemungkinan besar tingkat kesehatan juga rendah. Hal tersebut tentunya akan menambah kesulitan bagi para lansia dan keluarganya. Disatu sisi mereka hidup miskin dan harus memperoleh pekerjaan dan pendapatan yang layak. Lalu bagaimanakah kondisi mereka sebenarnya dan apa yang mestinya dilakukan pemerintah untuk menopang kelangsungan hidup mereka.

Sri Mulyani (1995), mengungkapkan bahwa bila leisure diasumsikan merupakan komoditas normal, peningkatan/penurunan pendapatan leisure ini akan menaikkan atau menurunkan permintaan terhadap leisure, yang berarti peningkatan / penurunan penyediaan waktu untuk bekerja. Ketika ekonomi keluarga memburuk, leisure menjadi relatif tidak terjangkau. Dengan kata lain, dari sisi mekanisme ini keluarga miskin tidak mampu untuk menikmati leisure. Selanjutnya perkembangan teoritis penawaran tenaga kerja memasukkan faktor dinamis, artinya dengan 


\section{Journal of Indonesian Applied Economics \\ Vol. 3 No. 2 Oktober 2009, 99-110}

mempertimbangkan dimensi waktu, tenaga kerja memiliki tingkah laku dan kendala yang berbedabeda sesuai dengan perkembangan usia mereka.

Berdasarkan hal tersebut di atas, para lansia yang tidak mampu menikmati leisure ini, menjadi amat tragis mengingat pada saat keinginan leisure itu muncul maka akan tertutup oleh tingginya kebutuhan kehidupan yang layak. Di lain pihak tingkah laku dan kendala (faktor dinamis) yang dihadapi para lansia pada usia yang mestinya sudah pensiun menjadi pelengkap polemik para lansia ini. Masalah ini nampak dengan semakin berkurangnya tenaga dan pikiran, yang disebabkan menurunnya kemampuan fisik para lansia. Pengaruh faktor psikologis sering marah, stress, egois dan daya ingat yang terus berkurang menjadi faktor penentu kurang diterimanya di pasar kerja.

Selain itu, faktor keluarga juga amat menentukan di dalam perjalanan hidup para lansia di mana selama ini diyakini bahwa dukungan penduduk lanjut usia merupakan tanggung jawab keluarga, terutama anak, sesuai dengan nilai yang di anut oleh kebanyakan masyarakat bahwa menjaga orang tua yang masih berusia lanjut merupakan kewajiban anak sebagai keturunannya (Noveria 2000). Disamping itu, banyak orang tua yang beranggapan bahwa anak merupakan tempat bergantung jika mereka sudah tua dan tidak sanggup hidup sendiri, baik karena alasan ekonomi maupun alasan kesehatan. Umpamanya, di bidang ekonomi, anggapan ini didukung oleh kenyataan kecilnya persentase penduduk lansia yang menerima pensiun yaitu 13 persen laki-laki dan 4 persen perempuan pada tahun 1989 (Chen dan Jones, 1989), yang menyebabkan tidak mampu mendukung kehidupan mereka secara ekonomi. Nilai-nilai penghargaan terhadap orang tua tersebut tidak akan dapat bertahan, mengingat perubahan nilai-nilai kehidupan di atas akan berubah seiring dengan perubahan jaman. Hal ini dibuktikan dengan mulai banyak kasus orang tua yang terlantar, mulai dari gelandangan sampai dengan menumpuknya orang tua di panti jompo. Kondisi ini memaksa mereka untuk tetap menjadi anggota pasar kerja sangatlah dimungkinkan di masa depan.

Di pihak lain, para pengusaha sangat jarang bahkan hampir tidak ada yang mau menerima para pekerja lansia mengingat kondisi perusahaan yang menuntut kebutuhan tenaga muda. Disamping itu, pemberian upah atau gaji lebih meringankan perusahaan untuk menerima orang muda dibandingkan lansia. Padahal dalam GBHN 1989 diamanatkan agar lansia yang masih sehat dan produktif dapat menyumbangkan pengetahuan dan pengalamannya, baik untuk diri sendiri maupun untuk masyarakat.

Hasil penelitian Djuhari dkk (1999), mengung kapkan bahwa krisis ekonomi yang melanda Indonesia akhir-akhir ini makin menamba merosotnya kualitas hidup lansia. Pendapatan yang tidak meningkat secara absolut di satu sisi diiringi dengan kenaikan harga-harga kebutuhan pokok yang melambung tinggi di sisi lain, menyebabkan daya beli penduduk termasuk lansia merosot tajam. Kenaikan harga tidak saja terjadi pada komoditas beras tetapi juga terjadi untuk barangbarang kebutuhan pokok lain seperti minyak goreng, minyak tanah, kecap, bumbu-bumbu dapur, dan sebagainya. Kenaikan harga barang-barang tersebut secara langsung telah berpengaruh pada kehidupan penduduk secara keseluruhan termasuk lansia.

Hal tersebut ditunjukkan lansia yang memperoleh upah/gaji lebih dari Rp. 300.000 hanya 11,61 persen. Persentase yang tertinggi terjadi pada golongan upah/gaji antara Rp. 50.000 sampai dengan 99.000 yaitu sebesar 30,22 persen, baik untuk laki-laki maupun perempuan. Padahal seperti diketahui bahwa dengan gaji Rp. 300.000 saja sudah sangat pas-pasan untuk kondisi saat ini yang berarti sangat sulit bagi lansia untuk dapat mencapai tingkat kehidupan yang berkualitas jika tidak ditopang dengan bantuan-bantuan lain. Rendahnya pendapatan yang diterima sebagian besar lansia diduga merupakan penyebab sebagian besar lansia bekerja penuh waktu.

\section{METODE PENELITIAN DAN ANALISIS DATA}

Tulisan ini mempergunakan data sekunder, dengan sumber utama dari SAKERTI (Survai Aspek Kehidupan Rumah Tangga Indonesia) tahun 1993 dan 1997. Disamping itu diambil juga 


\section{Faktor-Faktor yang Mempengaruhi Penduduk Lanjut Usia}

Affandi

Informasi dari SAKERNAS (Survai Angkatan Kerja Nasional) tahun 1966 dan dari SUPAS (Survai Penduduk Antar Sensus) tahun 1995.

Telah dijelaskan di atas bahwa dalam menyusun rencana pembangunan perlu keterangan dan informasi mengenai perkiraan kuantitas sumberdaya manusia, yang dapat diperoleh melalui hasil berbagai kegiatan pengumpulan data baik melalui sensus penduduk, survai atau registrasi. Sedangkan informasi mengenai perkiraan kuantitas sumberdaya manusia di masa depan dapat diperoleh dengan mengembangkan teknik perhitungan proyeksi penduduk . Suatu perkiraan, berdasarkan pada periode waktu dan cara perhitungannya dapat dibagi tiga antara lain, pertama, perkiraan antar sensus yaitu perkiraan keadaan penduduk antara dua sensus dimana kedua hasil sensus tersebut diperhitungkan. Kedua, perkiraan setelah sensus yaitu perkiraan keadaan penduduk yang harus disusun segera setelah penyelenggaraan sensus. Proyeksi atau perkiraan penduduk di masa depan adalah perkiraan keadaan penduduk berdasarkan hasil sensus terakhir. Proyeksi penduduk adalah suatu perhitungan ilmiah dengan aumsi-asumsi tertentu mengenai kecenderungan dari tingkat kelahiran, kematian, dan perpindahan penduduk di masa yang akan datang berdasarkan kecenderungan saat ini dan masa lalu.

Perhitungan proyeksi penduduk dapat dilakukan melalui dua pendekatan yaitu uniregional dan multiregional. Proyeksi yang dibuat selama ini umumnya menggunakan pendekatan uniregional. Demografi uniregional hanya memperhatikan penduduk di satu wilayah saja, maka semua angka (rate), termasuk angka "migration rate" menggunakan jumlah penduduk di wilayah tersebut sebagai penyebut. Khusus untuk angka migrasi, pendekatan yang digunakan dalam uniregional demografhy mengunakan angka migrasi neto yang pembaginya (denominator) adalah penduduk dari wilayah tersebut. Di pandang dari "resiko berpindah", angka tersebut tidak mengarah pada population at risk (penduduk yang berisiko terhadap suatu kejadian atau event) yang sebenarnya. Migrasi neto di hitung dari pengurangan antara migrasi masuk dan migrasi keluar dari suatu wilayah, yang berarti dua kelompok penduduk yang berbeda. Dengan demikian analisis perubahan penduduk dilakukan dengan hanya menekankan pada kejadian yang ada di daerah masing-masing tanpa memperhatikan perubahan yang terjadi didaerah asal, yang juga mempunyai pengaruh terhadap perubahan penduduk didaerah yang dituju.

Di awal abad dua puluh satu, kita akan memasuki abad globalisasi. Kemajuan transportasi, yang didukung semakin membaiknya kondisi sosial ekonomi merupakan gambaran penduduk yang semakin mobile. Akan semakin banyak orang, termasuk penduduk lansia, masuk ke suatu wilayah dengan berbagai alasan, maka perkembangan wilayah yang satu tidak terlepas dari kondisi yang ada di wilayah lain. Dengan semakin tingginya tingkat mobilitas penduduk maka pengukuran fertilitas, mortalitas dan migrasi di masing-masing wilayah tidak dapat dihitung sendiri-sendiri tetapi harus diperhitungkan secara bersama-sama. Oleh sebab itu analisis kependudukan disamping memperhatikan perubahan yang terjadi pada wilayahnya juga harus mengaitkannya dengan perubahan yang terjadi di wilayah lain.

Metode demografi multiregional merupakan pendekatan paling lengkap dan diharapkan mampu memenuhi kebutuhan tersebut. Hasil yang diperoleh melalui perhitungan proyeksi penduduk lansia dengan pendekatan demografi multiregional ini dapat juga digunakan dengan pengembangan lebih lanjut untuk memperoleh keterangan dan informasi berkaitan dengan karakteristik lain dari penduduk lansia, misalnya di bidang sosial dan ekonomi, seperti penduduk lansia yang masih bekerja atau mencari pekerjaan. Manfaat dari kajian demografi multiregional akan lebih terasa pada kondisi Indonesia di masa depan, dengan semakin membaiknya sarana transportasi dan komunikasi, serta dengan diberlakukannya kebijakan otonomi daerah. 


\section{Journal of Indonesian Applied Economics}

Vol. 3 No. 2 Oktober 2009, 99-110

\section{HASIL DAN PEMBAHASAN}

\section{Perspektif Demografi Uniregional dan Multiregional}

Perbedaan mendasar dari demorgafi uniregional dan multiregional terletak pada cara pendekatan terhadap persoalan dinamika kependudukan yang terjadi di suatu wilayah atau negara. Seperti di sebutkan oleh Roger (1995) dalam bukunya "Principles and Methods".

"Two fundamental features distinguish the multiregional from the uniregional perspective: the population being examined and the definition of rate offlow. The multiregional approach considers a national population as an interacting system of regional subpopulations; the uniregional approach examines each regional subpopulation one at a time."

Pada pendekatan uniregional, pengamatan terhadap penduduk regional dilakukan pada satu tempat tertentu. Sedangkan melalui pendekatan multiregional, penduduk tingkat nasional dipandang sebagai suatu sistem yang merupakan interaksi pada tingkat regional. Perspektif multiregional dalam analisis demografi memfokuskan jumlah penduduk dibeberapa wilayah misal propinsi, yang saling berhubungan secara simultan. satu sama lain pada suatu kejadian yang membentuk suatu sistem interaksi penduduk. Kejadian dimaksud adalah dengan adanya migrasi keluar dan masuk dari dan ke suatu wilayah, akan mengubah jumlah penduduk di masing-masing wilayah tersebut. Demografi multiregional merupakan deskripsi matematik dari evaluasi penduduk melalui ruang dan waktu, sebagai upaya untuk menghubungkan dan menyatukan arus perpindahan penduduk beberapa daerah (regional) ke dalam satu sistem penduduk multiregional. (Rogers 1994).

Selain itu, pada pendekatan uniregional yang di pandang hanya penduduk tunggal yang mempunyai resiko untuk bermigrasi keluar dan masuk", atau disebut juga migrasi neto. Berbeda dengan uniregional, dalam pendekatan demografi multiregional, antar daerah yang satu dengan yang lainnya yang dihubungkan oleh arus migrasi dianggap sebagai satu sistem yang saling berinteraksi. Pada pendekatan multiregional tingkat arus migrasi mengarah pada population at risk yang sesuai. Pola migrasi masuk dan keluar dianggap sebagai suatu sistem yang berhubungan satu sama lain dan bersifat simultan. Selain itu, arus migrasi yang diperhatikan hanya pada migrasi keluar saja (outmigration). Dengan demikian angka migrasi (rate of migration) selalu positif. Ini berarti pengamatan terhadap setiap penduduk di suatu wilayah hanya pada seberapa besar kemungkinan berisiko akan pindah.

Pertumbuhan, distribusi spasial, dan komposisi umur regional dan penduduk lansia multiregional ditentukan oleh kecenderungan mortalitas dan imigrasi di masa lampau, dengan mengasumsikan tidak ada migrasi internasional.

Karakteristik demografi penduduk lansia saat ini dan di masa yang lalu mengindikasikan tentang pentingnya membuat perkiraan penduduk lansia di masa depan, agar kemungkinan-kemungkinan yang dapat terjadi dimasa depan dapat di antisipasi sejak dini, di bawah ini disajikan hasil proyeksi penduduk lanjut usia dengan batasan umur 60 tahun dan 65 tahun ke atas (Tabel lampiran )

Inilah gambaran jumlah penduduk lansia di masa depan. Penduduk lansia (60 tahun ke atas) akan mengalami pertumbuhan penduduk yang relatif tinggi diperkirakan mulai sekitar periode 2005-2010. Dibandingkan periode lainnya, periode 2015-2020 merupakan periode dengan laju pertumbuhan penduduk lansia tertinggi diseluruh wilayah Indonesia baik Jawa dan Bali maupun di luar wilayah tersebut, dengan rata-rata pertumbuhan penduduk per tahun 4 persen. Agak sedikit mengalami kelambatan adalah pertumbuhan penduduk lansia perempuan di Jawa dan Bali, namun demikian mulai periode 2010-2015, pertumbuhan penduduknya terus mengalami kenaikan, dan di akhir periode proyeksi diperkirakan sekitar 3 persen.

Bila di kaji lebih mendalam, pertumbuhan penduduk lansia perempuan pada periode 20152020, yang lebih rendah dibandingkan lainnya ini tidak berarti jumlah absolut yang mulai berkurang. Pertumbuhan penduduk lansia hanya dipengaruhi oleh migrasi dan kematian. Jumlah absolut migran keluar dari Jawa dan Bali memang lebih tinggi di bandingkan migrasi yang masuk ke Jawa dan Bali, namun jumlahnya relatif tidak terlampau besar. Lebih rendahnya pertumbuhan penduduk lansia perempuan kemungkinan disebabkan jumlah absolut penduduk lansia perempuan 


\section{Faktor-Faktor yang Mempengaruhi Penduduk Lanjut Usia}

Affandi

di Jawa dan Bali yang memang relatif Sehingga pertambahan penduduk dari awal sampai akhir periode 2015-2020 tidak menghasilkan pertumbuhan penduduk setinggi pertumbuhan penduduk lansia laki-laki maupun perempuan di luar Jawa dan Bali.

Fenomena peningkatan jumlah penduduk lanjut usia (lansia), seperti digambarkan di atas dapat mempengaruhi perubahan struktur umur penduduk di Indonesia, yang berimplikasi pada masingmasing wilayah menyebabkan kecepatan proses pertumbuhan penduduk lansia menjadi berbedabeda. Selain itu, beberapa aktivitas yang masih banyak dilakukan penduduk lansia salah satunya adalah perpindahan dari satu wilayah ke wilayah lainnya. Hal ini tampak pada data migrasi risen keluar pada saat ini. Dengan mengasumsikan pola migrasi cenderung konstan atau sama seperti pola migrasi tahun 1995, perkiraan jumlah migrasi lansia dari 1995-2025 diperoleh dengan menggunakan rumus :

Dimana :

M : migran; $\mathrm{O}=$ keluar dan $\mathrm{I}=$ masuk

$\mathrm{P} \quad$ : jumlah penduduk yang dapat bertahan hidup dari umur tepat $\mathrm{x}$ umur $\mathrm{x}+5$

M : angka migrasi keluar (ASOMR) yang dihitung dari skedul model migrasi

$\mathrm{t}$ : tahun dasar

$\mathrm{x} \quad$ : kelompok umur

i : wilayah asal

j : wilayah tujuan

Seiring meningkatnya jumlah penduduk lansia, maka jumlah absolut migran lansia secara keseluruhan juga mengalami peningkatan. Jumlah migran lansia risen keluar di setiap periode di dua wilayah Jawa dan Bali dan luar Jawa dan Bali menunjukkan terjadinya peningkatan jumlah migran keluar penduduk lansia (60 tahun ke atas) di sepanjang periode proyeksi.

\section{Faktor Penentu Lansia Bekerja}

Beberapa karakteristik penduduk lansia berikut ini merupakan hasil analisis data SAKERTI. Dilihat dari segi jumlah penduduk, lansia perempuan umumnya lebih banyak dibanding lansia laki-laki. Dari 2990 lansia yang terpilih sebagai sampel penelitian, 45,8 persen adalah lansia laki-laki dan 54,2 persen lansia perempuan. Bila dibedakan menurut umur, maka jumlah penduduk lansia perempuan umur 60-64 tahun sebanyak 39,2 persen. Sedangkan untuk lansia laki-laki umur 60-64 tahun sebanyak 61,4 persen, sisanya 38,6 persen usia 70 tahun ke atas.

Selanjutnya dapat dilihat berbagai karakteristik lansia bekerja. Batasan bekerja yang digunakan adalah melakukan aktivitas ekonomi atau membantu melakukan aktivitas ekonomi dengan tujuan mendapatkan penghasilan atau keuntungan, minimal satu jam selama seminggu sebelum survei. Sedangkan batasan tidak bekerja adalah melakukan aktivitas lain selain bekerja, misalnya mengurus rumah tangga, pensiun, atau tidak dapat melakukan aktivitas karena cacat fisik atau mental termasuk jompo.

Dari 2990 lansia, 43,3 persen lansia masih berstatus bekerja, diantaranya 27,6 persen berusia 70 tahun keatas. Banyaknya lansia yang masih bekerja juga ditunjukkan dari hasil penelitian lembaga Demografi Fakultas Ekonomi Universitas Indonesia atau LDFEUI (1993), dan bahkan persentasenya lebih besar yaitu 62,25 persen. Lansia yang bekerja lebih banyak laki-laki $(66,4$ persen) dibanding lansia perempuan yang hanya 33,6 persen .

Masih banyaknya lansia yang bekerja mungkin berkaitan dengan masih banyak lansia yang berstatus sebagai kepala keluarga. Lansia yang berstatus kepala keluarga ini lebih banyak laki-laki ( 71,8 persen) daripada lansia perempuan ( 28,4 persen). Sehubungan dengan hal ini, dari sejumlah lansia yang bekerja, lebih dari 75 persen berstatus kawin. Jika dilihat menurut jenis kelamin dan 


\section{Journal of Indonesian Applied Economics \\ Vol. 3 No. 2 Oktober 2009, 99-110}

status kawin lansia, ternyata lansia laki-laki yang berstatus kawin 87,8 persen lebih banyak dibanding lansia perempuan yang berstatus kawin (64,6 persen).

Banyak alasan lansia masih bekerja, antara lain secara fisik dan mental lansia masih mampu dan kuat bekerja, desakan ekonomi, dan aktualisasi diri/emosi, seperti yang dikemukakan oleh Wirakartakusumah (1996). Alasan ekonomi yang menjadi sebab lansia bekerja juga dikemukakan oleh Sigit (1988), dengan masih bekerjanya lansia berarti mereka masih dapat menghidupi dirinya sendiri. Bahkan tidak sedikit lansia yang masih menghidupi keluarga anaknya yang tinggal bersamanya, karena mereka hidup dalam keluarga yang tidak mampu.

Berdasarkan pendidikan yang ditamatkan, semakin tinggi tingkat pendidikan lansia maka persentase yang bekerja cenderung semakin rendah. Dari 1288 lansia yang bekerja, lebih dari 85 persen lansia tidak sekolah sampai tamat SD. Hanya kurang dari 2 persen lansia yang bekerja mempunyai pendidikan diploma/universitas. Secara keseluruhan, hampir setengah dari jumlah lansia (49\%) berstatus tidak sekolah .

Lansia yang mencapai tingkat pendidikan tinggi umumnya adalah mereka yang dulunya mempunyai pekerjaan yang baik, sehingga sekarang pada masa tuanya mereka tidak perlu lagi bekerja karena sudah mampu menghidupi dirinya sendiri atau dengan keluarganya, tanpa harus bekerja. Mereka yang bekerja di sektor formal umumnya mendapat jaminan hari tua berupa uang pensiun. Sedangkan bagi mereka yang berpendidikan tinggi dan pada saat lansia masih bekerja, umumnya mereka merupakan lansia yang masih dibutuhkan "kemampuan atau kepandaiannya" atau sumbangan pikirannya. Sedangkan untuk lansia yang berpendidikan rendah, mereka terpaksa harus bekerja hanya untuk memenuhi kebutuhan saat itu saja, tanpa memikirkan adanya jaminan hari tua. Dengan demikian ketika memasuki usia tua mereka tidak mempunyai warisan atau tabungan yang dapat menjamin hari tua mereka.

Secara keseluruhan, tingkat pendidikan lansia umumnya rendah, seperti halnya kondisi pendidikan penduduk Indonesia pada umumnya. Kondisi demikian sangat dimaklumi mengingat kebanyakan lansia pada waktu mereka berada pada saat usia sekolah, mereka hidup dalam jaman penjajahan atau jaman perang, dan besar kemungkinan bahwa hanya sedikit dari mereka harus ikut perang, selain itu juga sarana pendidikan masih sangat terbatas dibanding sekarang.

Dilihat dari jenis kelamin, tingkat pendidikan lansia laki-laki lebih tinggi dibanding lansia perempuan, bahkan untuk lansia perempuan yang tidak sekolah jauh lebih banyak dibanding lansia laki-laki yaitu 71,5 persen dibanding 28,5 persen. Data SAKERTI ini hampir sama dengan hasil penelitian yang dilakukan oleh LDFEUI (1993) yaitu tingkat pendidikan lansia perempuan lebih rendah dari lansia laki-laki. Ada banyak kemungkinan lansia perempuan tidak sekolah, namun salah satu alasan utamanya adalah pada zaman dahulu perempuan umumnya tidak diijinkan untuk sekolah atau jika boleh sekolah paling cukup sampai SD saja. Umumnya masyarakat masih menganggap bahwa percuma saja perempuan sekolah tinggi, karena akhirnya ke dapur juga. Lansia perempuan yang sudah bisa mengenyam pendidikan tinggi umumnya berasal dari keluarga yang sudah tidak berpandangan "kolot" atau anak para "pejabat" yang mempunyai akses ke fasilitas pendidikan.

Tingkat pendidikan yang ditamatkan lansia sejalan dengan tingkat penghasilan yang diperoleh. Bagi lansia yang tidak/belum sekolah rata-rata penghasilannya lebih rendah dibanding lansia yang sekolah. Kecenderungan rata-rata penghasilan yang diperoleh lansia semakin tinggi seiring dengan semakin tingginya tingkat pendidikan yang dienyamnya. Sebagai contoh perbandingan, lansia yang tidak sekolah mendapat penghasilan rata-rata 54616,8 rupiah, sedangkan lansia yang berpendidikan diploma/universitas memperoleh penghasilan rata-rata 1.171.083 rupiah.

Selain itu, terdapat perbedaan jumlah lansia yang bekerja antara lansia yang tinggal di pedesaan dan perkotaan. Lebih dari separuh (57,5 persen) lansia tinggal di pedesaan. Selanjutnya dari semua lansia bekerja, 67,3 persen diantaranya tinggal di pedesaan. Umumnya lansia yang tinggal di daerah pedesaan masih banyak yang melakukan aktivitas bekerja, dan biasanya mereka bekerja di sektor pertanian. Sedangkan lansia yang tinggal di perkotaan umumnya menggeluti bidang industri atau jasa. 


\section{Faktor-Faktor yang Mempengaruhi Penduduk Lanjut Usia}

Affandi

Lansia yang bekerja umumnya ditunjang dengan kondisi kesehatannya, yang memungkinkan lansia tersebut bekerja. Hasil pengolahan data mengenai aktivitas melakukan kegiatan sehari-hari (ADL=Activity Daily Living) menunjukkan bahwa sebagian besar kondisi fisik lansia masih tergolong sehat, yaitu lebih dari 90 persen. Hanya saja untuk kondisi psikis sedikit lebih rendah dari kondisi fisiknya yaitu hanya sekitar 69 persen. Namun pada kenyataannya tidak tertutup kemungkinan ditemukannya lansia yang tergolong tidak sehat namun masih bekerja. Hal ini terjadi karena lansia tersebut berada pada kondisi sangat miskin yang mau tidak mau mereka harus tetap bekerja untuk mempertahankan hidup. Selain itu, ada juga lansia yang bekerja karena alasan gengsi untuk disebut "tua/jompo" sehingga demi kepentingan aktualisasi diri, mereka terpaksa bekerja.

\section{E. KESIMPULAN DAN REKOMENDASI}

Lansia atau lanjut usia berdasarkan suatu pandangan merupakan istilah yang dapat memiliki arti berbeda tergantung konsep atau pendekatan yang digunakan dalam mendefinisikannya. Salah satu pendekatan pendekatan yang dapat digunakan untuk mendefinisikan penduduk lansia (lanjut usia) adalah pendekatan menurut umur. Ada dua pandangan dalam mendefinisikan penduduk lansia menurut pendekatan menurut umur. Pertama, adalah definisi penduduk lansia menurut batasan umur 65 tahun ke atas. Kedua, adalah dengan batasan umur, 60 tahun ke atas. Dengan demikian definisi penduduk lansia menurut batasn umur, dapat menggunakan dua batasan umur tersebut, yaitu 65 tahun ke atas atau 60 tahun ke atas. Indonesia menggunakan batasan umur 60 tahun ke atas untuk mendefinisikan penduduk lansia.

Apabila trend penduduk di masa depan mengikuti tren penduduk saat ini dan di waktu yang lalu, maka diperkirakan bahwa secara kuantitas akan terjadi peningkatan jumlah penduduk lansia tertinggi diperkirakan akan dialami pada periode sekitar 2015-1020. Peningkatan jumlah penduduk lansia tersebut mengindikasikan kelangsungan hidup penduduk yang diperkirakan semakin panjang. Dilihat dari rasio jenis Kelamin yang merupakan perbandingan antara penduduk lansia laki-laki dan perempuan, penduduk lansia perempuan di wilayah Jawa dan bali maupun di luar wilayah Jawa dan bali, jumlahnya sedikit di atas jumlah penduduk lansia laki-laki.

Peningkatan jumlah penduduk lansia di masa depan baik di wilayah Jawa dan Bali maupun di luar Jawa dan Bali berpengaruh pula pada jumlah migran risen penduduk lansia. Dengan mengasumsikan pola migrasi yang konstan sepanjang periode proyeksi, dengan kata lain proporsi migran tetap sepanjang periode proyeksi maka peningkatan jumlah penduduk lansia berdampak pada meningkatnya jumlah migran risen lansia di masa depan baik laki-laki maupun perempuan.

Peran migrasi dalam proyeksi penduduk lansia baik dengan pendekatan niregional maupun multiregional, penting diperhatikan. Sebab, petumbuhan penduduk yang positif hanya disebabkan oleh unsur migrasi. Banyaknya migrasi lansia yang masuk dibandingkan yang keluar menyebabkan peningkatan jumlah penduduk lansia. Sebaliknya lebih banyaknya migrasi lansia yang keluar dibandingkan yang masuk akan mengakibatkan penurunan jumlah penduduk lansia di suatu wilayah. Inilah yang dpat mempengaruhi sebaran penduduk lansia. Peningkatan jumlah migrasi risen keluar dari suatu wilayah menuju wilayah lain di waktu-waktu mendatang, yaitu dari Jawa dan bali menuju keluar Jawa dan bali, dan sebaliknya , dapat juga digunakan sebagai gambaran tertjadinya peningkatan mobilitas penduduk lansia antar wilayah, yang dimungkinkan untuk memperoleh hasilnya melalui perhitungan dengan pendektan multiregional.

Hal ini disebabkan, perhitungan migrasi dengan pendekatan uniregional merupakan migrasi neto yang diperoleh dengan mengurangi antar migrasi masuk dan migrasi keluar. Perhitungan migrasi hanya menggambarkan perubahan penduduk yang mengakibatkan pertambahan atau pengurangan jumlah penduduk yang disebabkan oleh meigrasi. Migrasi positif berarti akan menambah jumlah penduduk di suatu wilayah, dan migrasi negatif akan mengurangi jumlah penduduk di suatu wilayah. 


\section{Journal of Indonesian Applied Economics \\ Vol. 3 No. 2 Oktober 2009, 99-110}

Berbeda dengan uniregional, perhitungan migrasi dengan pendekatan multiregional hanya menghitung migrasi keluar saja. Hal ini disebabkan migrasi keluar dari suatu wilayah asal merupakan migrasi masuk bagi wilayah yang dituju atau wilayah tujuan. Sehingga akan diperoleh informasi mengenai jumlah migran keluar dari suatu wilayah yang masuk atau menuju wilayah lain sebagai tujuannya. Dengan demikian akan diperoleh pola migrasi dari dua aliran migrasi penduduk di suatu wilayah asal ke wilayah tujuan, dan pola migrasi masuk dari wilayah tujuan ke wilayah asal, yang merupakan migrasi keluar dari wilayah tujuan ke wilayah asal.

Jika melihat kondisi lansia sekarang, sebenarnya lansia sudah tidak perlu bekerja untuk mencari nafkah apalagi sebagai tulang punggung keluarga. Meskipun masih bekerja, pekerjaan mereka harus terbatas pada pekerjaan untuk mengamalkan ilmu pengetahuan atau ketrampilan yang masih mereka miliki untuk diturunkan kepada generasi yang lebih muda. Namun kenyataannya masih banyak lansia yangs bekerja untuk mencari nafkah, bahkan sebagai tulang punggung keluarga. Berdasarkan analisis data SAKERTI mereka yang bekerja tersebut lebih banyak dari golongan berpendidikan rendah, pengeluaran rumah tangga rendah, sektor informal, dan tinggal di daerah pedesaan. Umumnya mereka masih terpaksa bekerja untuk mencari nafkah, mengingat kondisi ekonominya belum memenuhi kebutuhannya.

Dengan banyaknya lansia yang bekerja, perlu dipikirkan lapangan pekerjaan dan jenis pekerjaan yang cocok dengan kondisi mereka. Mereka masih tetap menjadi modal pembangunan, tapi mereka juga tidak mengurangi kesempatan bekerja untuk penduduk usia produktif. Namun kondisi seperti ini perlu juga didukung adanya jaminan sosial yang dapat membantu kebutuhan lansia, terutama untuk lansia yang bekerja di sektor informal. Mungkin untuk mewujudkan hal ini sangat sulit, karena program pemerintah belum tentu dapat menjangkau kelompok ini. Salah satu alternatif adalah dengan menggali potensi-potensi positif yang ada dalam keluarga dan masyarakat, misalnya menghormati orang tua, dan kegiatan-kegiatan yang berhubungan dengan lansia. Selain itu, dalam rangka mempersiapkan lansia masa datang, perlu upaya yang ditujukan kepada generasi yang lebih muda supaya mempersiapkan diri misalnya dengan cara menabung untuk hari tua, dan menjaga kesehatan.

\section{Rekomendasi}

Peningkatan penduduk lansia bagi sebagian masyarakat merupakan suatu fenomena yang harus segera diantisipasi, namun bagi sebagian lagi mungkin menganggap belum terlalu mendesak dibanding masalah-masalah kependudukan lainnya. Alasan kelompok terakhir ini adalah masih banyaknya persoalan kependudukan yang harus segera diantisipasi seperti masalah-masalah yang berhubungan dengan bayi, balita dan ibu. Namun terlepas dari perbedaan pandangan tersebut, suatu perencanaan kependudukan tetap harus mempertimbangkan masalah yang akan terjadi dengan adanya peningkatan penduduk lansia ini. Salah satu hal yang perlu diperhatikan yaitu berkaitan dengan kondisi lansia yang bekerja dengan persentase sekitar 40 persen.

Di satu pihak diharapkan lansia tidak menjadi beban penduduk usia produktif, namun di pihak lain belum banyak perhatian terhadap nasib para pekerja lansia. Bahkan lansia yang bekerja tersebut banyak yang mempunyai penghasilan yang tergolong rendah, atau mungkin kondisi pekerjaan mereka dianggap kurang sesuai dengan kondisi fisik, dan psikis lansia.

Negara-negara maju yang sudah lebih dahulu mengalami era lansia, perhatian terhadap lansia umumnya ditekankan pada usaha untuk mensejahterakan lansia tersebut. Bagi lansia yang masih ingin bekerja, mereka dipekerjakan di tempat-tempat sosial, atau musium. Bahkan dari segi sarana dan prasarana, mereka sudah lebih beruntung karena mendapat fasilitas-fasilitas yang memudahkan mereka untuk melakukan aktivitas. Salah satu contoh adalah bis umum, yang menyediakan fasilitas tempat duduk khusus dan tempat naik untuk penumpang yang tergolong disable dan lansia. Selain itu, ada potongan-potongan harga dari beberapa produk tertentu, dan potongan harga dari layanan 
angkutan. Kemudahan-kemudahan tersebut juga didukung dengan adanya jaminan sosial yang sudah bagus.

Bagi Indonesia, sebagai negara dengan jumlah penduduk yang tergolong cukup banyak, perhatian terhadap lansia sudah dapat dirasakan. Beberapa contoh perhatian terhadap lansia antara lain adanya potongan harga untuk layanan angkutan umum terutama untuk angkutan udara. Selain itu, secara nasional sudah dimulai untuk dibentuk suatu lembaga independen lansia yang diharapkan menjadi suatu institusi yang dapat mempersatukan atau menaungi berbagai institusi lansia lainnya. Pembahasan rinci mengenai seluk beluk lembaga tersebut dilaksanakan berkaitan dengan pelaksanaan Kongres Nasional Lansia Pertama yang diresmikan oleh Wakil Presiden RI pada tanggal 30 - 31 Januari 2001. Salah satu hal pokok yang dapat ditarik dari pesan Wakil Presiden adalah bahwa generasi muda harus diberi bekal budi pekerti supaya dapat menghargai para lansia.

Sebenarnya gerakan sayang lansia sudah banyak dicoba untuk dilakukan di Indonesia, namun tidak semua kegiatan tersebut dapat berjalan secara berkesinambungan terutama yang berupa program pemerintah. Sekarang ini banyak pertikulir atau yayasan-yayasan yang menyediakan sarana berupa panti, klub-klub lansia dan pelayanan konsultasi bagi lansia. Namun umumnya jangkauannya masih terbatas bagi lansia yang berasal dari status sosial ekonomi menengah ke atas. Sedangkan bagi lansia dari golongan ekonomi ke bawah, aksesnya lebih rendah dibandingkan mereka. Oleh karena itu dilakukan upaya untuk mensejahterakan lansia dengan salah satu upayanya adalah pemberdayaan lansia. Berkaitan dengan ini, perlu adanya penggalian terhadap potensipotensi yang ada pada keluarga dan masyarakat yang dapat mendukung kehidupan lansia. Mengingat kondisi sekarang ini keluarga sudah mengalami pergeseran dari bentuk keluarga luas ke keluarga batih.

\section{DAFTAR PUSTAKA}

1984. Migration, Urbanization, and spatial Population Dunamics. Westviem Press, London.

, 1997. Profil Penduduk Lanjut Usia Indonesia. Jakarta.

, 1997a,Penduduk Indonesia 1995.Seri S No.2. Hasil Survei Penduduk Antar Sensus (Supas 1995), Jakarta.

, 1997b. Survey Angkatan Kerja Nasional (SAKERNAS) 1996. Jakarta: BPS.

, 1998a. Data dan Informasi Penduduk lansia di Indonesia. Sistem Informasi Kependudukan dan Keluarga (SIDUGA). Jakarta.

Biro Pusat Statistik, 1997. Laporan Sosial Indonesia (Lanjut Usia/ Lansia), Jakarta.

Biro Pusat Statistik. 1998. Laporan Sosial Indonesia 1997: Lanjut Usia (Lansia). Jakarta: BPS.

Cicih, Lilis Heri Mis. 1999. "Status Disabilitas, Morbiditas, dan Gizi Penduduk Indonesia. Analisa data SAKERTI 1993". Thesis S2 Kependudukan dan Ketengakerjaan Pasca Sarjana Universitas Indonesia. Jakarta.

Desi, Sita. 1997. "Faktor Penentu Bekerja Diantara Para Penduduk Usia Lanjut. Analisa data SAKERTI 1993". Thesis S2 Kependudukan dan ketenagakerjaan Pasca Sarjana universitas Indonesia. Jakarta.

Kantor Menteri Negara Kependudukan / BKKBN, 1998. Demografi Multiregional. Jakarta. 
Journal of Indonesian Applied Economics

Vol. 3 No. 2 Oktober 2009, 99-110

Kantor Menteri Negara Transmigrasi dan Kependudukan Republik Indonesia dan United National Populatio Fund (UNFPA). 2000. Rencana Aksi Nasional Untuk Kesejahteraan Lansia. Jakarta.

Lembaga Demografi Fakultas Ekonomi universitas Indonesia. 1993. Pengembangan Kebijakan Tingkah Laku Tentang Konsekuensi dari Penduduk Lansia: Kasus Indonesia. Jakarta: lembaga Dmografi Fakultas Ekonomi Indonesia.

Rogers, Andrei. 1995. Multiregional Demography : principles, Methods and Extensions, John Wiley \& Sons Ltd, England.

Sigit, Hananto. 1998. A Socio Economic profile of Elderly independent Indonesia. Jakarta: Biro Pusat Statistik.

Suhartinah, Florentia. 1998. "Social Welfare Services for The Elderly independent Indonesia". Dalam Populatio Aging independent Asia (ASEAN Population Studies series no. 108), united nation, New york.

Wirakartakusumah, M. Djuhari, Hisar Sirait, dan Zainul Hidayat. 1996. Pelibatan Penduduk Usia Lanjut dalam Keluarga. Jakarta: Lembaga Demografi Fakultas Ekonomi Universitas Indonesia. 